\title{
TOMISTYCZNA «LA RÉVOLUTION SEXUELLE» O. ADRIANO OLIVY OP
}

W renomowanym dominikańskim wydawnictwie „Cerf” ukazała się książka ojca Adriano Olivy OP, której celem jest „duszpasterska” (pastoral) reinterpretacja tradycyjnego nauczania Kościoła na temat powtórnych związków osób rozwiedzionych (les divorcés remariés) oraz par homoseksualnych (les couples homosexuels) ${ }^{1}$. Książkę tę można potraktować jako głos w dyskusji, która toczy się w różnych kręgach kościelnych od jakiegoś czasu. Można ją wziąć nawet za element ,,polityki” watykańskiej Autora, wszak jest on tam osobą prominentną - szefem Komisji Leonińskiej, powołanej do edycji krytycznej dzieł św. Tomasza z Akwinu, czyli niejako „urzędowym” tomistą. I w tym miejscu zaczyna się problem, z powodu którego - nie uczestnicząc we wspomnianych dyskusjach ani nie prowadząc polityki watykańskiej - należało się zająć książką o. Olivy: swoje propozycje opiera on bowiem na myśli i tekstach św. Tomasza. Wprawdzie znajdujemy w pracy omówienia późniejszej tradycji - Autor podkreśla ciągle duszpasterski charakter swoich propozycji - jednak fundamentem

\footnotetext{
${ }^{1}$ Omawiana pozycja to: A. O 1 i v a, Amours. L'Église, les divorcés remariés, les couples homosexuels, Paris 2015, ss. 166. Podane w tekście artykułu strony odnoszą się do tej właśnie pozycji (przyp. Red.).
} 
ustaleń czyni tomizm. W niniejszej recenzji chcemy zając się tym właśnie aspektem książki Amours.

Swoje rozważania o małżeństwie o. Oliva rozpoczyna (s. 7) od cytatu z Tomaszowej Summa contra Gentiles, gdzie św. Tomasz mówi, że między mężem i żoną zachodzi amicitia maxima (największa przyjaźń), czego znakiem jest nie tylko życie seksualne (actus carnalis copulae), ale także współżycie we wspólnocie domowej (domestica conversationis consortium) ${ }^{2}$. Sama analiza ontycznej struktury małżeństwa jest w zasadzie zgodna z tekstem Akwinaty, jednak wyprowadzone z niej konsekwencje wymierzone są wprost w jego nauczanie moralne o małżeństwie i rodzinie. To te wysnute przez o. Olivę konsekwencje prowadzą go do sformułowania wniosku o rewizję katechizmowego nauczania na temat divorsés remariés. Powoduje to, że ocena rozważań o. Olivy na temat małżeństwa nie jest prosta, bo tezy słuszne wymieszane są tam z błędnymi - $\mathrm{z}$ tomistycznego punktu widzenia - wnioskami.

Przywołany „fundamentalny” cytat ilustruje dobrze (raczej niewyszukaną) metodę reinterpretacji nauczania Tomasza, polegającą na wyrwaniu z szerszego kontekstu jednego zdania i ,zlecenie” mu uzasadniania czegoś zgoła innego, niż ma to, co znajduje się w tekście Akwinaty. Metodę tę zresztą o. Oliva stosuje także w odniesieniu do homoseksualizmu. Otóż przytoczone wyżej zdanie, że przyjaźń małżonków wydaje się być największą z przyjaźni międzyludzkich, jest $\mathrm{w}$ tekście Tomasza jednym $\mathrm{z}$ argumentów za nierozerwalnością (indivisibilitas) małżeństwa i pochodzi z rozdziału na ten właśnie temat. Z tekstu więc o nierozerwalności małżeństwa o. Oliva bierze zdanie, które w jego książce tę nierozerwalność w jakiś sposób osłabia.

2 Summa contra Gentiles, III, 123. Wszystkie cytaty z tekstów św. Tomasza, a także wszystkie odwołania odnoszą się do internetowej edycji jego dzieł, dostępnej na portalu: www.corpusthomisticum.org (20 VI 2016). 


\section{PROBLEM OSÓB ROZWIEDZIONYCH ZNAJDUJĄCYCH SIĘ W POWTÓRNYCH ZWIĄZKACH (LES DIVORCÉS REMARIÉS)}

Analiza Tomaszowego ujęcia małżeństwa jest u o. Olivy poprawna, a jego uwagi na temat jej zniekształcania w późniejszych dziejach teologii moralnej, a zwłaszcza prawa kanonicznego, interesujące i pouczające. Otóż o. Oliva zwraca uwagę, że tym, co konstytuuje małżeństwo, jest miłość (s. 15). Z niej dopiero wywodzą się skutki, które stanowią cele małżeństwa. Tomasz tę miłość nazywa formą małżeństwa, która stanowi jego pierwszą doskonałość (s. 24) ${ }^{3}$. Doskonałość wtórną stanowią działania z tej formy pochodzące, czyli zrodzenie i wychowanie potomstwa. Pierwsze jest pochodną życia seksualnego, drugie - współżycia i wzajemnego pomagania sobie. Wynika z tego kilka ważnych konsekwencji, przede wszystkim zaś ta, że życie seksualne, a co za tym idzie, także zrodzenie potomstwa, nie stanowią istoty małżeństwa, lecz jego skutek ${ }^{4}$. Podejmując szerzej ten temat, Tomasz odróżnia istotę, przyczynę i cel małżeństwa. Istotą jest zjednoczenie (coniunctio), przyczyną są zaślubiny (desponsatio), a skutkiem - potomstwo (proles) $)^{5}$ W tym zakresie więc trochę nietrafiona jest krytyka Olivy zawarta w „Odpowiedzi pięciu dominikanów" z 12 lutego 2015 roku$^{6}$. Nie jest bowiem prawdą, że „Oliva oddziela dwie istotowe części małżeństwa, które Akwinata

3 Summa theologiae, III, 29, 2 c. Forma autem matrimonii consistit in quadam indivisibili coniunctione animorum (,Formę małżeństwa stanowi zaś pewien niewidzialny duchowy związek”). To ten „niewidzialny duchowy związek” Akwinata nazwał w Summa contra Gentiles ,największą przyjaźnią”. Przyjaźń zaś u Tomasza jest odmianą miłości.

${ }^{4}$ W oparciu o tę zasadę Tomasz podkreśla, że związek Maryi i Józefa był prawdziwym małżeństwem.

5 Summa theologiae, suppl. 44, 3 c.

${ }^{6}$ Aquinas \& Homosexuality. Five Dominicans Respond to Adriano Oliva, www. firstthings.com/web-exclusives/2015/12/aquinas-homosexuality (20 VI 2016). 
mocno trzyma razem"’ , bo św. Tomasz odróżnia właśnie istotę, przyczynę i skutek lub cel małżeństwa, i prokreacja rzeczywiście nie stanowi istoty małżeństwa, lecz jego skutek lub cel. Zdanie więc z Komentarza do Sentencji, że ,głównym celem małżeństwa jest dobro potomstwa"8 nie stoi w sprzeczności z tezą, że istotą małżeństwa jest zjednoczenie, cel bowiem jakiejś rzeczy nie jest tym samym co jej istota. Gołosłowne jest więc stwierdzenie krytyków Olivy, że nic z tego, co mówi nie ma u Akwinaty ${ }^{9}$. Problemem jest tu nie interpretacja tekstów Akwinaty, lecz wyprowadzone z niej wnioski.

Jak się wydaje, teoria małżeństwa w ujęciu św. Tomasza prowadzi w sposób jednoznaczny do tezy, że jest ono świadomym, dobrowolnym i trwałym związkiem mężczyzny i kobiety, zapoczątkowującym rodzinę i wszystko, co się z tym wiąże, czyli wspólny dom, zrodzenie i wychowanie dzieci, uczestnictwo w szerszych wspólnotach. Tomasz expressis verbis przeciwstawia się poligamii i rozwodom ${ }^{10}$.

Adriano Oliva nie podejmuje tematu rozwodów i niejako płynne przechodzi do opisu sytuacji divorcés remariés, wychodząc od przedstawienia ich obecnej sytuacji kanonicznej w Kościele katolickim. Ogólnym warunkiem dopuszczenia ich do sakramentów jest

7 Oliva separates the two essential parts of marriage that Aquinas firmly holds together. Tamże.

${ }^{8}$ Bonum prolis sit principalis matrimonii finis. Scriptum super Sententiis, lib. 4 d. 33 q. 1 a. 2 co.

9 Podobnie jak stwierdzenie, że ,dla Akwinaty więź małżeństwa ma dwojaki cel: 1) prokreacja i edukacja dzieci oraz 2) wzrost małżonków w miłości i wzajemnym wspieraniu się we wspólnym życiu" (For Aquinas, the bond of matrimony has a two-fold purpose: 1) the pro-creation and raising of children, and 2) the couple's growth in love and mutual support through their life together). Inaczej, jak widzieliśmy, przedstawia to Tomasz, wzajemną miłość uważa za istotę małżeństwa, natomiast pomaganie sobie i wspieranie się wiąże z trudem wychowania potomstwa. Formuła zaś przytoczona przez krytyków pochodzi z Kodeksu Prawa Kanonicznego.

10 Jak wspomniano, kluczowy dla Olivy cytat pochodzi z rozdz. 123 z III księgi Summa contra Gentiles, dotyczącego nierozerwalności małżeństwa, natomiast cytat przywołany prze jego krytyków, mówiący, że głównym celem małżeństwa jest dobro dzieci (Scriptum super Sententiis, lib. 4 d. 33 q. 1 a. 2 co) - z uzasadnienia monogamicznego charakteru małżeństwa. 
rozwiązanie tego powtórnego związku. Jednak uczyniono tu wyjątek w sytuacji wychowania dzieci lub innych, uniemożliwiających rozstanie. Wtedy jednak warunkiem przystąpienia do sakramentu pokuty jest rezygnacja z pożycia seksualnego. I tu mamy powód, dla którego tyle miejsca poświęca O. Oliva na udowodnienie, że św. Tomasz życia seksualnego nie uważa za istotę małżeństwa (s. 19-21) ${ }^{11}$. Stanowi to dla niego argument dla tezy, że pożycie seksualne divorcés remariés, nie będąc czymś istotnym w małżeństwie, nie stanowi też istotnej przeszkody w dopuszczeniu ich do sakramentów. Zwłaszcza, że - jak podkreśla - łączy ich amicitia maxima, która stanowi istotę związku małżeńskiego. Wychodząc zaś od stwierdzenia, że w najnowszym nauczaniu kościelnym unika się zrównywania divorcés remariés z konkubinatami, proponuje, aby papież skorzystał z ,władzy kluczy” i na wzór miłosiernego ojca z przypowieści o synu marnotrawnym, dopuścił divorcés remariés do spowiedzi i komunii, zastrzegając jednocześnie, że nie oznacza to zrównania ich związków z małżeństwami i tym bardziej nie oznacza możliwości błogosławienia takich związków w Kościele.

Odnosząc się do tego wszystkiego należy zgłosić dwa zespoły uwag. Pierwszy - bardziej szczegółowy - dotyczy sposobu wykorzystywania przez o. Olivę myśli św. Tomasza. W omawianej wyżej sprawie problemem nie jest, jak już wspomniano, przedstawienie i interpretacja nauczania Tomasza - o. Oliva przedstawia je trafniej niż jego krytycy - ale wniosków stawianych na podstawie tego nauczania. Przede wszystkim autor Amours przechodzi jakby do porządku dziennego nad sakramentalnymi małżeństwami divorcés remariés, w których nadal pozostają na mocy przyczyny tych małżeństw, czyli sakramentalnych zaślubin. Tu przecież tkwi główny problem i niemówienie o nim nie oznacza, że go nie ma. Jest nim bowiem pewna niekonsekwencja tkwiąca w propozycji o. Olivy, dotyczącej dopuszczenia divorcés remariés do pokuty i eucharystii bez prawa do sakramentalnego usankcjonowania nowego związku. Skoro

${ }^{11}$ Choć Akwinata pisze o tym wprost, np. w: Summa theologiae, 42, 4 c: carnalis commixtio de secunda perfectione matrimonii, et non prima [est]. 
bowiem będąc w nowych związkach są w nich w stanie łaski uświęcającej, to jaki jest powód odmówienia im błogosławieństwa tego nowego związku? ${ }^{12}$ Dopuszczenie divorsés remariés do spowiedzi i Eucharystii oznaczałoby całkowitą akceptację ich sytuacji moralnej, bo czymże innym jest rozgrzeszenie w sakramencie pokuty? W tej sytuacji trudno uzasadnić odmowę pobłogosławienia ich związku i uznania go za pełne małżeństwo chrześcijańskie. Ojciec Oliva przywołuje w tym kontekście, jak już wspomniano, przypowieść o synu marnotrawnym (Łk 15,11-32), który powraca do ojca i otrzymuje przebaczenie ku niezadowoleniu syna wiernego. Apeluje, aby w Kościele niesakramentalne małżeństwa osób rozwiedzionych potraktować jak syna marnotrawnego, zaś małżeństwa sakramentalne - jak syna zawsze wiernego (s. 128). Nie odnosi się jednak do cytowanej niżej jasnej wypowiedzi Jezusa na temat nierozerwalności małżeństwa, która - jak się wydaje - była od zawsze przeszkodą w rozluźnieniu prawa małżeńskiego w Kościele, którego „surowość” od niepamiętnych czasów powodowała duże kłopoty także dla samej instytucji kościelnej - można przypomnieć sprawę zakończenia małżeństwa Henryka VIII z Katarzyną Aragońską w 1533 roku czy Napoleona Bonaparte z Józefiną de Beauharnais w 1809 roku. Propozycja o. Olivy stanowi wyłom $\mathrm{w}$ zasadzie nierozerwalności małżeństwa i z tego punktu widzenia nie wydaje się być zgodna z nauczaniem nie tylko św. Tomasza z Akwinu ale i Jezusa Chrystusa.

W ten sposób możemy płynnie przejść do drugiego zespołu uwag, które są bardziej ogólne. Słuszny jest postulat o. Olivy, aby w różnych tomistycznych rozważaniach szczegółowych, moralnych lub duszpasterskich, wychodzić od fundamentu, którym jest metafizyka Tomasza z Akwinu. Sam jednak myli chyba metafizykę bytu z dość

12 Owszem, można wskazać analogie z sytuacją samotnych rozwiedzionych, którzy mogą być rozgrzeszeni i przyjmować komunię, ale gdy chcą pozostać w stanie łaski uświęcającej nie mogą zawrzeć nowych związków. Adriano Oliva proponuje jakby krok dalej nie zwracając uwagi na to, że w pierwszej sytuacji nie podważa się zasady nierozerwalności małżeństwa, czego nie można powiedzieć o propozycji o. Oliwy. 
już szczegółowymi zagadnieniami antropologicznymi. Owszem, mają one u Tomasza metafizyczny charakter, ale nie należą do problematyki wyjściowej; są raczej już wnioskami analiz metafizycznych. Podejmując bowiem temat osobowej miłości i wspólnot osób, trzeba najpierw zwrócić uwagę na ich status bytowy. Osoba bowiem jest podmiotem relacji i wspólnot, stanowi substancję, byt samodzielny. Miłość jest relacją osób, bytem niesamodzielnym, przypadłością podmiotowaną przez osoby, jako byty samodzielne. Wynika z tego pierwsza i zasadnicza konsekwencja także moralna: to relacje zależą od podmiotujących je osób. A więc to miłość zależy od kochających się osób, a nie te osoby od niej. Wręcz przeciwnie: miłość ma taki charakter, jaki wyznaczą jej osoby - inna łączy małżonków, inna rodziców i dzieci, jeszcze inna - ludzi i Boga. I miłość zależy od wiążących się nią osób: wzrasta, gdy ją chronią i rozwijają, a zanika, gdy nie jest pielęgnowana i broniona ${ }^{13}$. Druga konstatacja stanowi także konsekwencję odróżnienia istoty od przypadłości - tego, co ważne od tego, co drugorzędne. Otóż miłość jest relacją osobową, której istotę stanowi akceptująca i życzliwa, niczym nie warunkowana współobecność osób, gdyż najgłębszą jej podstawą w osobach jest sama ich realność. Ta miłość w istocie swej jest „niewidoczna”, a na zewnątrz przejawia się w postaci różnych znaków, przede wszystkim zaś rozmowy - to po sposobie rozmawiania bezbłędnie poznajemy jej charakter, poziom i intensywność. Także małżeństwo - jak trafnie zauważył André Maurois - to „długa rozmowa”, a nie przede wszystkim „układ seksualny”. I małżeństwa rozpadają się nieporównanie częściej z powodu braku porozumienia, „nie dogadania się”, niż niedopasowania seksualnego. Dlatego określenie małżeństwa jako remedium concupiscentiae („uśmierzanie pożądliwości”) stanowi dość radykalną redukcję tego, czym jest małżeństwo i przez to zaciemnia istotę więzi małżeńskiej jako „wspólnoty życia i miłości”, co o. Oliva słusznie krytykuje. Jednak słuszna diagnoza to tylko wstęp do dobrej terapii. O. Oliva „przestrzelił się” zalecając dopuszczenie

13 Zob. A. A d a m, Milost'v teológii Wincenta Granata v kontexte filozofie Tomáša Akvinského, „Rocznik Tomistyczny”, 1(2012), s. 49-63. 
divorsés remariés do pełni życia sakramentalnego z wyłączeniem sakramentu małżeństwa.

Akt seksualny należy do tego samego zbioru znaków miłości, co rozmowa, gesty, podarunki. Każdy taki znak z jednej strony, jak już wspomniano, ujawnia poziom i charakter miłości, z drugiej zaś - powoduje jej pogłębianie czy zintensyfikowanie. Owszem, znak seksualny to znak wyjątkowy, jakościowo różny od innych, niosący doniosłe konsekwencje, ale zawsze mający charakter przypadłości w stosunku do istoty miłości. Ujawnia szczególną więź dwojga ludzi i tę wieź pogłębia. Chrystus, który w swoim nauczaniu moralnym nie skupiał się zbytnio na dziedzinie życia seksualnego, jednak akt seksualny w stanowczy sposób zarezerwował dla małżeństwa, jako związku mężczyzny i kobiety: „Kto oddala żonę swoją, a bierze inną, popełnia cudzołóstwo względem niej. I jeśli żona opuści swego męża, a wyjdzie za innego, popełnia cudzołóstwo"14. Wiadomo, dlaczego Chrystus tak tę sprawę stawia: w małżeństwie rodzą się i wychowują dzieci. Ojciec i matka są dla nich pierwszą wspólnotą, a ich miłość - niezbędnym środowiskiem wzrastania i to już od pierwszych chwil życia. Argument ten jest także argumentem Tomasza z Akwinu za nierozerwalnością małżeństwa. Ludzie bowiem, jak to bardzo słusznie zauważył Jacques Maritain, rodzą swoje dzieci na sposób ludzki, czyli na sposób bytów, które są cielesne i duchowe zarazem. Nie tylko więc powołują je do życia biologicznego i przygotowują do samodzielności, lecz także wychowują, starają się przekazać to, czym żyją, swoje wartości, pozostają w relacjach przez całe życie ${ }^{15}$.

${ }_{14}$ Mk 10, 11-12. Miejsca paralelne: Mt 5, 31; 19, 9; Łk 16, 18.

15 „Owe instynktowne dążności i skłonności zostały opanowane i przeniesione w dynamizm pojmowania intelektu i we właściwą sferę natury ludzkiej jako typowo takiej, tzn. jako obdarzonej i przesiąkniętej rozumem. (...) Tak więc będziemy mieli na przykład skłonności do rodzenia dzieci nie tylko fizycznie, ale również do formowania ich etyki, do jedności i stabilności rodziny. Oto skłonności prawdziwie ludzkie, nawet jeśli dotyczą tego, co w człowieku wspólne ze zwierzętami. Natura obmyła się w wodach intelektu". J. M a r i t a i n, Pisma filozoficzne, (tłum. J. Fenrychowa), Kraków 1988, s. 270 ; zob. też : M. K r a s n o dę b s k i, Teoria 


\section{PROBLEM PAR HOMOSEKSUALNYCH (LES COUPLES HOMOSEXUELS)}

Ta ostatnia uwaga może być dobrym wstępem do analizy i oceny poglądów o. Adriano Olivy na temat par homoseksualnych. Sam homoseksualizm o. Oliva określa jako ,inklinację seksualną osoby do osób tej samej płci"16 i rozszerza tę definicję na osoby biseksualne i transseksualne ${ }^{17}$. Odróżnia ponadto samą inklinację od aktu (s. 83).

Znalezienie podstaw akceptacji aktów homoseksualnych w myśli św. Tomasza jest niezwykle trudne, gdyż Akwinata wielokrotnie pisze, że stosunki homoseksualne (coitus masculorum) są przeciwne naturze i potępia je jako wadę sodomską (sodomiticum vitium) ${ }^{18}$. O. Oliva zdaje sobie $\mathrm{z}$ tego w pełni sprawę, gdy pisze, że św. Tomasz nie opracował teorii homoseksualizmu, i jak wszyscy jego współcześni, kiedy pisze o różnych postaciach rozwiązłości, zawiera w nich grzech sodomii ${ }^{19}$. Uważa jednak, że można w tekstach Akwinaty szukać akceptacji stosunków homoseksualnych i związków homoseksualistów. Dodaje bowiem zaraz, że pewną genialną intuicję znajduje w jego refleksji, dotyczącej nie tyle porządku moralnego, co metafizycznego (s. 75). O. Oliva dużo obiecuje sobie po analizie owej Tomaszowej intuition géniale: „Wychodząc od głównych zasad jego doktryny, będziemy rozwijać te intuicje Tomasza, aż do ostatecznych

osobowych relacji istnieniowych jako fundament rodziny $w$ filozofii Mieczysława Gogacza, „Rocznik Tomistyczny”, 3(2014), s. 45-59.

${ }_{16}$ Inclination, y compris sexuelle, d une personne vers de personnes du même sexe. Amours, s. 77.

17 Tamże, s. 157 przypis 7. Podtrzymuje to rozszerzenie także w ramach wniosków pisząc, że inklinacje homoseksualna, biseksualna i transseksualna są ,connaturels" i wobec czego osoby je przejawiające nie są „odmienne” (différente) od osób heteroseksualnych. Amours, s. 117.

18 Np. Summa theologiae, II-II, 154, 11 c ; Super Epistolam B. Pauli ad Romanos lectura, c. 1, 1. 8. Wersja polska: To m a s z A k w in u, Wykład Listu do Rzymian, (tłum. J. Salij), Poznań 1987, rozdz. 1, wykład 8.

19 Amours, s. 75 : Saint Thomas n`a pas élaboré une théorie de 1’homosexualité et, comme tous ses contemporains, quand il traite de différentes espèces de luxure, il y inclut le péché de sodomie. 
konsekwencji, do wypracowania nowych perspektyw rozumienia homoseksualizmu i integracji osób i związków homoseksualnych w łonie wspólnoty chrześcijańskiej" (s. 75-76) ${ }^{20}$. Te konsekwencje kreśli bardzo szeroko: zmiana nauczania Magisterium Kościoła, rozwój antropologii, teologii, egzegezy i szczególnie owocny rozwój tomistycznej tradycji teologicznej (s. 76).

Jak zatem wygląda owa genialna intuicja metafizyczna? O. Oliva znalazł ją w tzw. Traktacie o uczuciach w Summa theologiae ${ }^{21}$. Ważny wydaje się tu szerszy kontekst tego artykułu ${ }^{22}$, który dotyczy pytania o przyjemności nienaturalne. Artykuł ten należy do kwestii poświęconej przyjemności (delectatio). Przyjemność zaś jest u Tomasza uczuciem wynikającym z osiągniecia pożądanego dobra, jest więc zaspokojeniem pożądania (appetitus) i niejako spoczynkiem pożądania w tym dobru. Dobrem zaś w dziedzinie uczuć dla każdej istoty jest to, co jej współnaturalnie i współmierne (unicuique... est bonum id quod est sibi connaturale et proportionatum) $)^{23}$. Artykuł ma wyjaśnić, jak to się dzieje, że niektórzy ludzie doznają przyjemności w rzeczach niezgodnych z naturą. Podajemy cały korpus artykułu Tomasza, podobnie jak czyni to o. Oliva (s. 122-124).

${ }^{20}$ À partir de principes généraux de sa doctrine, nous développerons cette intuition de Thomas jusqu’à ses dernières conséquences, afin d’élaborer des perspectives nouvelles, de compréhension de l'homosexualité et d'intégration de personnes et de couples homosexuels au sein de la communauté chrétienne.

${ }^{21}$ Summa theologiae, I-II, 22-48.

${ }^{22} \mathrm{Na}$ co słusznie zwracają uwagę krytykujący Olivę dominikanie w pkt. 4 cytowanej wyżej wypowiedzi (przypis 5). Tomasz ponadto wielokrotnie podkreśla, że ludzkich uczuć nie da się odseparować od działań intelektu i woli, a zatem także od sprawności poznawczych i moralnych. Zob. S. K o z e r s k i, Stosunek cnót do uczuć w filozofii św. Tomasza z Akwinu, na przykładzie cnoty męstwa, „Rocznik Tomistyczny", 3(2014), s. 99-112.

${ }^{23}$ Summa theologiae, I-II, 27, 1c. Tomasz ponadto wielokrotnie podkreśla, że ludzkich uczuć nie da się odseparować od działań intelektu i woli, a zatem także od sprawności poznawczych i moralnych 
Respondeo dicendum quod naturale dicitur quod est secundum naturam, ut dicitur in II Physic. Natura autem in homine dupliciter sumi potest. Uno modo, prout intellectus et ratio est potissime hominis natura, quia secundum eam homo in specie constituitur. Et secundum hoc, naturales delectationes hominum dici possunt quae sunt in eo quod convenit homini secundum rationem, sicut delectari in contemplatione veritatis, et in actibus virtutum, est naturale homini. Alio modo potest sumi natura in homine secundum quod condividitur rationi, id scilicet quod est commune homini et aliis, praecipue quod rationi non obedit. Et secundum hoc, ea quae pertinent ad conservationem corporis, vel secundum individuum, ut cibus, potus, lectus, et huiusmodi, vel secundum speciem, sicut venereorum usus, dicuntur homini delectabilia naturaliter.
Należy powiedzieć, że naturalnym nazywa się to, co zgodne z naturą, jak mówi się w II ks. Fizyki. Naturę zaś w człowieku można ująć dwojako. W pierwszy najlepszy sposób natura ludzka ujęta jest według intelektu i rozumu, gdyż dzięki niemu konstytuuje się człowiek jako gatunek. Zgodnie z tym, naturalnymi przyjemnościami ludzkimi mogą być nazwane te, które najbardziej wynikają z tego, co dokonuje się według rozumu, tak jak przyjemności w kontemplacji prawdy i w aktach cnót są naturalne dla człowieka. W inny sposób można ująć naturę w człowieku według tego, co oddziela się od rozumu, a mianowicie tego, co jest wspólne człowiekowi i innym [istotom żywym], głównie zaś tego, co nie podlega rozumowi. I według tego [ujęcia] te przyjemności nazywa się naturalnymi dla człowieka, które należą do ochrony ciała, albo w odniesieniu do jednostki, jak pokarm, napój, sen itp. albo w odniesieniu do gatunku, jak życie seksualne. 
Secundum utrasque autem delectationes, contingit aliquas esse innaturales, simpliciter loquendo, sed connaturales secundum quid. Contingit enim in aliquo individuo corrumpi aliquod principiorum naturalium speciei; et sic id quod est contra naturam speciei, fieri per accidens naturale huic individuo; sicut huic aquae calefactae est naturale quod calefaciat. Ita igitur contingit quod id quod est contra naturam hominis, vel quantum ad rationem, vel quantum ad corporis conservationem, fiat huic homini connaturale, propter aliquam corruptionem naturae in eo existentem. Quae quidem corruptio potest esse vel ex parte corporis, sive ex aegritudine, sicut febricitantibus dulcia videntur amara et e converso; sive propter malam complexionem, sicut aliqui delectantur in comestione terrae vel carbonum, vel aliquorum huiusmodi, vel etiam ex parte animae, sicut propter consuetudinem aliqui, delectantur in comedendo homines, vel in coitu bestiarum aut masculorum, aut aliorum huiusmodi, quae non sunt secundum naturam humanam.
Według obydwu [tych ujęć] mogą istnieć pewne nienaturalne przyjemności ujęte wprost, lecz współnaturalne, gdy ujmie się je pod jakimś względem. Zdarza się bowiem w niektórych jednostkach zniszczenie jakiegoś naturalnego pryncypium gatunkowego i wtedy to, co jest przeciw naturze gatunku przypadłościowo może stać się naturalne dla tej jednostki, tak naturalne jest dla ciepłej wody, że ogrzewa. W ten sposób zdarza się, że coś jest przeciw naturze ludzkiej albo ze względu na rozum, albo ze względu na chronienie ciała, staje się współnaturalne dla człowieka ze względu na pewne zepsucie znajdującej się w nim natury. To zepsucie zaś może pochodzić albo ze strony ciała, a więc z choroby, jak dla trawionych gorączką słodkie wydaje się gorzkie i na odwrót, lub ze względu na zły ustrój, jak wtedy, gdy ktoś doznaje przyjemności w jedzeniu ziemi lub węgla, względnie czegoś podobnego, albo ze strony duszy, tak jak przez przyzwyczajenie niektórzy doznają przyjemności zjadaniu ludzi albo w stosunkach płciowych ze zwierzętami lub mężczyznami względnie innymi tego rodzaju rzeczami, które nie są zgodne $\mathrm{z}$ ludzką naturą. 
Adriano Oliva zwraca uwagę, że homoseksualizm jest wprawdzie niezgodny z naturą ludzką pojętą ogólnie, ale w niektórych jednostkach wynika z ich natury indywidualnej - jest więc dla tych jednostek czymś naturalnym. Wielokrotnie podkreśla też, że homoseksualizm Akwinata sytuuje po stronie duszy - ex parte animae (s. 78, 81, 9091, 93-94). Co więcej, w źródle homoseksualizmu w duszy, którym jest według Tomasza przyzwyczajenie (consuetudo), o. Oliva widzi uznanie Akwinaty dla koncepcji płci socjokulturowej (s. 80). Taki wniosek z analizy końcowego fragmentu zacytowanej wypowiedzi Tomasza jest dla o. Olivy punktem wyjścia do wyciągnięcia owych „ostatecznych konsekwencji”, o których wspomniał na początku swej książki. Te konsekwencje są następujące: pierwszą z nich nazywa „Wnioskiem fundamentalnym” (s. 85) i polega ona na odróżnieniu homoseksualizmu jako wyłącznie chęci użycia osoby tej samej płci do zaspokojenia popędu seksualnego dla samej tylko przyjemności, od homoseksualizmu jako skłonności do kochania i zjednoczenia się z osobą tej samej płci²4. Dla o. Olivy nie wynika z tego, że związki homoseksualne mają mieć charakter ,platoniczny”, lecz zwraca uwagę, że przyjemność seksualna o charakterze homoseksualnym,,gdy jest usytuowana po stronie duszy, ma swoje pryncypium w bycie rozumnym, inteligencji i woli osoby homoseksualnej" 25 . Akt homoseksualny ,realizowany z miłością (l’amour), która tryska w duszy, pouczany przez miłość (la charité), ten akt nie będzie zawierał

${ }^{24}$ Warto może zauważyć, że nie jest to wynalazek o. Olivy, lecz jeden z wniosków klasycznej już krytyki utylitaryzmu, prowadzącej do sformułowania tzw. normy personalistycznej, która została przeprowadzona przez Karola Wojtyłę w książce Miłość i odpowiedzialność. Szerzej: A. A n d r z ej u k, Norma personalistyczna jako sposób ochrony osób w książce „Miłość i odpowiedzialnośc” Karola Wojtyly, w: J. Czartoszewski (red.), Ochrona życia i zdrowia człowieka w nauczaniu Jana Pawta II, Warszawa 2006, s. 185 - 191.

25 Puisqu'il est situé du côté de l'âme, a son principe dans l'être ratonnel, intelligence et volonté, de la personne homosexuelle. Amours, s. 85. Jeśli taki akt - stwierdza nieco dalej - jest tak jak i u par heteroseksualnych, regulowany przez cnotę czystości, wtedy akt homoseksualny przyczynia się do zjednoczenia związku homoseksualnego w miłości i nie zachodzi w nim grzech sodomii (tamże, s. 112-113). 
żadnego grzechu"26. W tym wypadku - podkreśla - homoseksualizm nie może być uznany za niezgodny z naturą, pomimo że nie koresponduje z ogólną naturą „,ogólną” gatunku (s. 85-86). Z tego punktu widzenia trzeba „zaktualizować zasady moralne” (le principe moral que nous définirions aujoud 'hui) poprzez „odwrócenie” (le pivot) „całej moralności św. Tomasza” (s. 91). W ramach tego „odwrócenia” należy akt homoseksualny, gdy jest „czynem świadomym i odpowiedzialnym" (l'agir conscien et responsable), uznać za moralny i nie naruszający przykazań, gdyż odnoszą się one do natury pojętej ogólnie, a nie natury indywidualnej (s. 92). Fakt ten osoba homoseksualna musi - zdaniem o. Olivy - określić w swym prasumieniu (synderesis) i roztropnie osądzić w sumieniu (s. 91).

Zebrawszy to wszystko, dominikański tomista formułuje szereg postulatów „społecznych" zmierzających do stworzenia homoseksualistom perspektyw realizacji siebie jako osób. W pierwszej kolejności dotyczą one społeczności rodzinnej i kościelnej. Pierwsza z nich powinna wykazać pełną akceptację i otoczyć troską homoseksualistę, gdyż odrzucenie społeczne, a przede wszystkim brak akceptacji najbliższych owocuje takimi, spotykanymi często wśród homoseksualistów postawami, jak niedojrzałość emocjonalna, nieumiejętność nawiązania stałych relacji, wchodzenie w przypadkowe związki pozbawione prawdziwej miłości (s. 118). Wspólnota kościelna natomiast powinna stworzyć homoseksualistom warunki realizowania w pełni ich chrześcijańskiego powołania. Dlatego o. Oliva wnosi o korektę nauczania zawartego w Katechizmie Kościoła Katolickiego (s. 115-116, 118-119). Kolejny zespół postulatów dotyczy społeczności cywilnej, która - zdaniem autora Amours - powinna zapewnić możliwość zawierania związków homoseksualnych, gdy jest to naturalne prawo

${ }^{26}$ Réalisé avec l'amour qui jaillit de l'âme, instruit par la charité, un tel acte ne compontera aucoun péché. Amours, s. 113. Co więcej, w miłości homoseksualnej o. Oliva dostrzega cechy tej miłości, którą Jezus Chrystus na kartach Ewangelii proponuje dla każdego wierzącego: akceptację sprawiającą, że miłujący staje się przyjacielem samego Boga (s. 134 przypis 35). 
homoseksualistów wynikające $\mathrm{z}$ ich indywidualnej natury ${ }^{27}$. Nie można jednak - zdaniem o. Olivy - w imię wierności Tomaszowi z Akwinu zrównać par homoseksualnych z małżeństwami, gdyż pary te siłą rzeczy nie mogą być otwarte na prokreację $(\mathrm{s.} .96,120)^{28}$, jednakże państwo powinno zagwarantować związkom (les unions) homoseksualnym prawa podobne do praw par (les couples) heteroseksualnych (s. 114), zwłaszcza, gdy się weźmie pod uwagę, że prokreacja nie wchodzi już (n`appartient déjà pas) do istoty małżeństwa (s. 115) ${ }^{29}$.

Pierwsza uwaga, jaka nasuwa się po zapoznaniu się z tymi rozważaniami, dotyczy metodologii o. Olivy i zawiera się w pytaniu, czy można poglądami Tomasza z Akwinu nazywać wnioski wysnute $\mathrm{z}$ jego ujęć, które jednak całkowicie przeczą jego poglądom

27 Amours, s. 96. O. Oliva pisze, że Akwinata zna sytuację społeczną, w której funkcjonowały związki homoseksualne, o czym świadczy jego komentarz do fragmentu Polityki Arystotelesa, w którym opisany jest ustrój starożytnej Krety. Oliva żałuje, że Tomasz nie podjął, co zapowiadał, rozważań na temat moralnego aspektu tej instytucji w ustroju Krety. Gdy jednak dokładnie przyjrzymy się odnośnemu tekstowi Akwinaty (Sententia libri Politicorum, lib. 2 1.15 n. 5) to jest on wyłącznie zreferowaniem tekstu Arystotelesa (Polityka, II, 7, 5; 1272 a 20-25) i to Arystoteles zapowiada ocenę omawianej instytucji kreteńskiej, której to oceny, jak podają wydawcy, nie ma w żadnym z zachowanych pism Stagiryty. Zob. A r i s t o te l i s, Politica libri I-II, 11, trans. Guillelmus de Morbeka, ed. Michaud-Quantisn 1961; korzystam z tekstu zdigitalizoiwanego na płycie CD: ALD-1 - Aristoteles Latinus, 2003. Polska wersja: A r y s t o te le s, Dzieła wszystkie, t. 6, Warszawa 2001, s. 70. Co jednak ciekawe, to w stosunku do tekstu Arystotelesa, z którego Tomasz korzystał (przekład Wilhelma z Moerbeke) odnośnie do dopuszczonych na Krecie przez prawodawcę stosunków homoseksualnych (concessit turpem masculorum coitum), Akwinata dodał przymiotnik turpem (ohydny, haniebny) którego nie ma w tekście Polityki.

${ }^{28}$ Inna sprawa, to udział homoseksualistów w wychowaniu dzieci, co wiąże się z problemem prawa do adopcji dzieci przez pary homoseksualne; o. Oliva nie podejmuje tego tematu pisząc, że przekracza to ramy tematu podjętego w książce Amours (s. 120, 161 przypis 37, 163 przypis 56).

29 Trudno oprzeć się wrażeniu daleko idącej zbieżności tego co pisze o. Oliva z opiniami postulatami środowisk LGBT. 
wyrażonym expressis verbis? ${ }^{30}$ Trzeba by wykazać, że poglądy Akwinaty są albo całkowicie niespójne, albo jednak ostrożniej przypisywać mu swoje własne wnioski.

Niezależnie od tej ogólnej uwagi metodologicznej, musimy wyraźnie stwierdzić, że wnioski wysunięte przez o. Olivę są na gruncie tomizmu całkowicie nietrafne, bo żadną miarą nie wynikają z ujęć Tomasza, ani z tych przytoczonych przez dominikanina, ani z innych, wyrażonych w licznych tekstach antropologicznych i moralnych. Przede wszystkim, w cytowanym artykule, przywołanie stosunków homoseksualnych należy do grupy przykładów na przyjemności nienaturalne (delectatio innaturalis). O. Oliva zdaje się jakby nie zauważać odpowiedzi na postawioną kwestię. Kwestia ta brzmi: videtur, quod nulla delectatio sit innaturalis (wydaje się, że żadna przyjemność nie jest nienaturalna). Odpowiedź - jak to zazwyczaj w Summa theologiae - zaprzecza przedstawionej wątpliwości (tak też jest i w tym wypadku): Po przedstawieniu dwóch ujęć natury ludzkiej Akwinata pisze: secundum utrasque autem delectationes, contingit aliquas esse innaturales (według obydwu [tych ujęć] mogą istnieć pewne nienaturalne przyjemności). I to jest zasadnicza odpowiedź Akwinaty. Powstaje jednak pytanie: dlaczego coś niezgodnego z naturą wywołuje przyjemność, czyli pewną pozytywną reakcję pożądania? I Tomasz starannie wyjaśnia, że z powodu zepsucia zasad natury (principiorum naturalium) coś niezgodnego z naturą może odpowiadać zepsutej naturze jednostkowej, czyli być z nią współnaturalne (connaturales). Pozostałe przykłady Tomasza niemal ośmieszają interpretację o. Olivy, co bezlitośnie wykorzystują krytycy o. Olivy z jego własnego zakonu. Bernhard Blankenhorn, Catherine Joseph Droste, Efrem Jindráček, Dominic Legge oraz Thomas Joseph White piszą: ,Jeśli, jak twierdzi Oliva, Tomasz chce powiedzieć, że skłonność homoseksualna pochodzi z najgłębszej części duszy danej osoby, to samo powinno dotyczyć nauczania Akwinaty na temat kanibalizmu i zoofilii. Jednak jest to ewidentny absurd. Akwinata nie

${ }^{30}$ Np. na s. 115 o. Oliva pisze, że św. Tomasz „chroni” (sauvegarde) prawdę o inklinacji osób homoseksualnych - oczywiście w jej ujęciu przez dominikanina. 
mógł chcieć powiedzieć, że kanibale i zoofile, wyrażają najbardziej wewnętrzną skłonność swojego bytu. To właśnie dlatego Tomasz pisze, że są to nawyki. Dlaczego te trzy wady pochodzą z duszy? Ponieważ spotyka się je wśród ludzi. Krowy nie jedzą krów. Tomasz zauważa, że w świecie zwierząt te trzy wady nie występują. Mniemanie Olivy, że według Tomasza, niektórzy ludzie rodzą się z duszą homoseksualną, jest aberracją z punktu widzenia interpretacji tekstu. Oznaczałoby to, że dla św. Tomasza pewni ludzie rodzą się z duszą kanibala, a inni z duszą zoofila ${ }^{31}$ ".

Wydaje się, że w analizach o. Olivy zabrakło odróżnienia tego, co zgodne z naturą (secundum naturam) od tego, co współnaturalne (connaturale) i zwrócenia uwagi, że coś, co jest przeciwne naturze (contra naturam) może być współnaturalne naturze zepsutej (natura corrupta). To tak jak morfina jest dobra dla uśmierzenia bólu pooperacyjnego, a chemioterapia do zabicia nowotworu. Jednakże zepsucie natury nie jest stanem naturalnym. Wyjściem z zepsucia jest albo naprawienie, albo zniszczenie. Tymczasem o. Oliva proponuje cos trzeciego: akceptację zepsucia. Nie znajdziemy u Tomasza podstaw do takiej akceptacji. Co więcej, Tomasz w odniesieniu do homoseksualizmu, kanibalizmu i zoofilii stwierdza, że pochodzą one z przyzwyczajenia (propter consuetudinem). Przyzwyczajenie zaś pochodzi z powtarzania czynności, jest więc czym nabytym i przez to - zgodnie z przysłowiem, które zna także Akwinata - staje się

${ }^{31}$ If, as Oliva proposes, Thomas means that the homosexual inclination comes from the most intimate part of the person's soul, then the same reading must apply to Aquinas's mention of cannibalism and bestiality. Yet this is clearly absurd. Aquinas cannot mean that cannibals and practitioners of bestiality are following the inclinations of their most intimate selves. That is precisely why Thomas mentions custom. Why do all three vices come from the soul? Because they are especially found among human beings. Cows don't eat cows. Thomas thinks that most animals do not practice the three mentioned vices. Olivia's claim that, for Thomas, some persons are born with a homosexual soul, is outrageous as a matter of textual interpretation. It would mean that, for Aquinas, others are born with cannibalistic souls, and others with souls geared to practice bestiality. 
„jakby drugą naturą"32. Ale jeśli owa „druga natura” skłania do czegoś moralnie złego, to nie znajduje wyrozumiałości w tekstach Tomasza ${ }^{33}$ :

Malitia aliquorum hominum potest dici naturalis, vel propter consuetudinem, quae est altera natura; vel propter naturalem inclinationem ex parte naturae sensitivae, ad aliquam inordinatam passionem, sicut quidam dicuntur naturaliter iracundi vel concupiscentes; non autem ex parte naturae intellectualis.
Zło [moralne] niektórych ludzi może być nazwane naturalnym albo ze względu na przyzwyczajenie, które jest drugą naturą, albo ze względu na naturalną skłonność zmysłowej części natury do jakiegoś nieuporządkowanego uczucia, tak jak o niektórych mówi się, że są z natury złośliwi lub pożądliwi; nie dotyczy to jednak intelektualnej części natury.

Warto też zaznaczyć, że przyzwyczajenie nie jest - jak chciałby o. Oliva - ufundowane (fondée), według Tomasza, w duszy, lecz bardziej w ciele i stanowi to, co późniejsza tradycja nazwała nawykiem, czyli bezrefleksyjnym skutkiem wyćwiczenia jakieś czynności $^{34}$. Potwierdza to św. Tomasz pisząc, że ,przyzwyczajenie działa w sposób konieczny nie wprost, lecz głównie w nagłych przypadkach, natomiast jeśli się podejmie nad nim namysł, wtedy można działać przeciwko przyzwyczajeniu". Nie jest też u Tomasza przyzwyczajenie

${ }^{32}$ Np. w Summa theologiae I-II, 32, 2, ad 3 pisze: quod id quod est consuetum, efficitur delectabile, inquantum efficitur naturale, nam consuetudo est quasi altera natura (to, do czego przyzwyczailiśmy się, sprawia zadowolenie, o ile jest naturalne, gdyż przyzwyczajenie jest jakby drugą naturą).

${ }_{33}$ Summa theologiae, I, 63, 4, ad 2. Zob. też: P. B e 1 i n a - P r a ż m ow s k a, Dlaczego czynimy zło? Trójpodziat przyczyn zła moralnego według św. Tomasza z Akwinu, „Rocznik Tomistyczny”, 3(2014), s. 113-127.

${ }^{34}$ Consuetudo facit necessitatem non simpliciter, sed in repentinis praecipue; nam ex deliberatione quantumcumque consuetus potest contra consuetudinem agere. Quaestiones disputatae de malo, q. 6, ad 24. 
synonimem współnaturalności ${ }^{35}$. Co więcej, podaje on wskazówkę, jak przeciwstawiać się złym nawykom - należy podejmować nad nimi namysł. Jest tu więc coś ze współczesnych terapii psychologicznych ${ }^{36}$, jednakże jeszcze bardziej jest to wyraz przekonania o rozumnym charakterze człowieka i tym, że intelekt jest pierwszą i najważniejszą władzą w człowieku, która jest w stanie kierować wszystkimi innymi władzami, uczuciami i skłonnościami.

Możemy zarzucić Tomaszowi, że jego koncepcja natury nie jest jednoznaczna, że waha się pomiędzy różnymi jej ujęciami: bardziej arystotelesowskim (rozumna natura człowieka) i bardziej boecjańskim (wspólna natura ludzka - rodzajowa lub gatunkowa), że miesza z tym jeszcze potoczne ujęcia nawyku, jako „drugiej natury” i zepsucia, jako natury jednostkowej. Jednakże nie znajdujemy w jego tekstach nawet cienia akceptacji dla praktyk homoseksualnych. Ba, raczej możemy mu zarzucać zbytni rygoryzm w sprawach seksualnych, gdyż bardzo negatywnie ocenia akty seksualne wykluczające prokreację (masturbacja, oralne, analne) ${ }^{37}$ :

${ }^{35}$ Amours, s. 86: consuetudo... est chez luis ynonime de connaturel (consuetudo est altera natura). Znamienne jest zresztą, że znaczenia słowa consuetudo o. Oliva nie szuka u św. Tomasza, lecz we współczesnych słownikach łaciny (zob. przypis 20 na s.159) i właściwie całkowicie przeinacza znaczenia pojęć „,consuetudo” i ,habitus", uważając ten ostatni za przejaw wyćwiczenia organów cielesnych (s. 86).

${ }^{36}$ Zob. A. Te r r u w e, C. B a a rs, Integracja psychiczna. O nerwicach $i$ ich leczeniu, (tłum. W. Unolt), Poznań 1987; rec. A. A n d r z e j u k „Studia Philosophiae Christianae", 27(1991)1, s. 148-157.

37 Summa theologiae, II-II, 154, 11 c. 
Ibi est determinata luxuriae species ubi specialis ratio deformitatis occurrit quae facit indecentem actum venereum. Quod quidem potest esse dupliciter. Uno quidem modo, quia repugnat rationi rectae, quod est commune in omni vitio luxuriae. Alio modo, quia etiam, super hoc, repugnat ipsi ordini naturali venerei actus qui convenit humanae speciei, quod dicitur vitium contra naturam. Quod quidem potest pluribus modis contingere. Uno quidem modo, si absque omni concubitu, causa delectationis venereae, pollutio procuretur, quod pertinet ad peccatum immunditiae, quam quidam mollitiem vocant. Alio modo, si fiat per concubitum ad rem non eiusdem speciei, quod vocatur bestialitas. Tertio modo, si fiat per concubitum ad non debitum sexum, puta masculi ad masculum vel feminae ad feminam, ut apostolus dicit, ad Rom. I, quod dicitur sodomiticum vitium. Quarto, si non servetur naturalis modus concumbendi, aut quantum ad instrumentum non debitum; aut quantum ad alios monstruosos et bestiales concumbendi modos.
Gdzie jest określona postać rozwiązłości, tam zachodzi specjalny powód spaczenia, powodujący niestosowność aktu seksualnego. To zaś może zachodzić na dwa sposoby. Pierwszy sposób, który przeciwstawia się prawemu rozumowi jest wspólny dla wszystkich wad rozwiązłości. Sposób drugi ponadto przeciwstawia się samemu naturalnemu porządkowi aktu seksualnego, który jest odpowiedni dla rodzaju ludzkiego, co nazywa się wadą przeciwko naturze. To zaś może zachodzić na wiele sposobów. Pierwszy sposób polega na tym, gdy ktoś bez stosunku, dla przyjemności seksualnej, wywołuje wytrysk nasienia, co stanowi grzech nieczystości, przez niektórych nazywany zniewieściałym. Inny sposób, dokonuje się przez spółkowanie z osobnikiem spoza swego gatunku, co nazywa się bestialstwem. Trzeci sposób zachodzi przez spółkowanie z niewłaściwą płcią, czyli mężczyzna z mężczyzną, a kobieta z kobietą, jak mówi Apostoł w I ks. Listu do Rzymian, co nazywa się wadą sodomską. Czwarty, gdy nie stosuje się naturalnego sposobu spółkowania, albo przez używanie niewłaściwych narządów, albo w inny zdziwaczały lub zdziczały sposób. 
Przytoczona wypowiedź nie pozostawia wątpliwości co do Tomaszowej oceny stosunków homoseksualnych. Warto jednak zwrócić uwagę na uzasadnienie tych, bądź co bądź, rygorystycznych poglądów: sprzeciwienie się naturalnemu porządkowi (repugnatio ordini naturali). A więc argumentem jest tu znowuż natura, a dokładnie sprzeniewierzenie się wyznaczanemu przez nią porządkowi. Nie widać więc rozłamu pomiędzy antropologicznymi poglądami Tomasza, a jego ocenami moralnymi, a na tym rozłamie próbował budować swoje ujęcia o. Oliva pisząc, o ,genialnej intuicji”, która znajduje się w rozważaniach z porządku metafizycznego, a nie moralnego ${ }^{38}$. Co więcej, owa „genialna intuicja” ma u samego Tomasza dość kruchą podstawę, którą jest jego nie do końca jednoznaczna, a na pewno nie zawsze spójna koncepcja natury i tego, co naturalne, o czym już wspomniano. Nie mniej jednak, z żadnego punktu widzenia: metafizycznego, antropologicznego czy moralnego nie da się na gruncie tekstów i myśli Tomasza z Akwinu uzasadnić etycznej akceptacji aktywności homoseksualnej.

$$
* * *
$$

Św. Tomasz z Akwinu jest twórcą całościowej teorii relacji międzyludzkich, w których dominującą pozycję zajmuje miłość. Ją Akwinata uważa za podstawowy motyw wszelkich ludzkich poczynań. Jest ona dla niego czymś najważniejszym w życiu człowieka, bo wiąże go z innymi ludźmi, a także z Bogiem. Wśród odmian i postaci miłości Tomasz specjalnie wyróżnia przyjaźń, którą uważa za najlepszą postać miłości międzyludzkiej. Na niej, jego zdaniem, budują się wszelkie ludzkie wspólnoty, od małżeństwa i rodziny począwszy. Jej swoista odmiana, caritas, łączy człowieka z Bogiem. Wielu autorów tomistycznych podejmowało ten wątek myśli Tomasza; literatura tego tematu jest naprawdę obszerna. Omawiając miłość i przyjaźń Tomasz nie podejmuje tematu płci i stosunków płciowych,

38 Nous reconstrons chez lui, dans in réflexion d’ordre non pas d'bord moral, mais métaphisique, une intuition géniale. Amours, s. 75. 
uważając je słusznie za jeden ze znaków miłości, zarezerwowanych w chrześcijaństwie dla małżeństwa, o czym wspomina, podkreślając jednak, ze małżeństwo nie polega na tej fizycznej więzi, lecz na specjalnym rodzaju przyjaźni, która może być nazwana największą przyjaźnią. Omawiając samą przyjaźń, np. w wykładzie VIII i IX księgi Etyki nikomachejskiej Arystotelesa także nie zatrzymuje się na sprawach seksualnych. Można więc powiedzieć, że dla Tomasza pierwszoplanową sprawą międzyludzką jest miłość i przyjaźń, które nie łączą się u niego w sposób konieczny z życiem seksualnym. To życie - nawet w ramach miłości - umieszczone jest w określonym, przynależnym mu miejscu. Temat seksu nie dominuje więc nie tylko w antropologii Tomasza, ale nawet w jego teorii miłości.

Tymczasem w chrześcijaństwie, a może nawet szczególnie w katolicyzmie, występuje od pewnego czasu zbytnie - jak się wydaje skoncentrowanie uwagi na sprawach seksu i zarazem sprowadzenie go poziomu zwierzęcego, jako wyłącznie sposobu prokreacji (od czego nie jest także wolny Tomasz z Akwinu!). Teologowie moralni, a zwłaszcza kanoniści, opisali i (unormowali!) ludzkie życie seksualne z iście pornograficzną precyzją, rozważając szczegółowo warunki i sposoby dokonywania aktów seksualnych, zapominając jakby przy tym, że chodzi o relacje między osobami ludzkimi, a nie między zwierzętami i że cel tych relacji jest nie tylko ,animalny”, lecz także ,racjonalny” i osobowy (skoro człowiek to animal rationale). Zwłaszcza, że w przypadku zwierząt wszelkich regulacji w tej mierze dokonuje sama natura, określając czas i miejsce rozmnażania. To graniczące z obsesją skupienie się na sprawach seksu, przysłaniające często poważniejsze kwestie moralne, jak choćby sprawa ochrony życia, własności, prawdy, nie ominęła także komentatora św. Tomasza w osobie o. Olivy ${ }^{39}$.

${ }^{39}$ Zbytni nacisk na sprawy seksu w nauczaniu moralności chrześcijańskiej paradoksalnie skutkuje budowaniem wzorców osobowych jako ludzi aseksualnych - tak przedstawiani są często np. duchowni i święci. Szerzej o zderzeniu tomistycznej teorii osoby ze współczesnymi wizjami człowieka zob. U. W o 1 s k a, Wizja człowieka 
Podstawowym więc wnioskiem metafizycznej analizy w tomistycznej antropologii jest ukazanie we właściwych proporcjach osoby ludzkiej, jej relacji, jej działań i jej seksualności. Owa seksualność ani nie określa osoby, ani nie determinuje jej działań - owszem, należy do człowieka jako istoty cielesno-duchowej, ale nie w większym stopniu jak np. przyciąganie ziemskie, konieczność oddychania, snu, jedzenia i picia.

Książka o. Adriano Olivy, a raczej głoszone w niej poglądy, jest całkowitym nieporozumieniem w tym znaczeniu, że zupełnie nietrafnie wybrano podstawy dla głoszonych poglądów. Ujęcia św. Tomasza nie nadają się zupełnie do uzasadnienie zarówno dopuszczenia do sakramentów Kościoła divorcés remariés, jak i instytucjonalnej akceptacji par homoseksualnych.

\section{Father Adriano Oliva's Thomistic « la révolution sexuelle » Summary}

In the Dominican reputable publishing 'Cerf' was published a book of father Adriano Oliva OP. The aim of this book is 'pastoral' reinterpretation of traditional teaching of the Church about second marriage of people who are divorced (les divorces remariés) and homosexual couples (les couples homosexuels). A. Oliva is basing his suggestions on texts of St. Thomas Aquinas.

Father Oliva his considerations about marriage begins (p. 7) from quotation from Thomas' Summa contra Gentiles where Thomas says that between husband and wife there is occured amicitia maxima (the largest friendship). The sign of amicitia maxima is not only sex life (actus carnalis copulae) but also the co-existence in the household (domestica conversationis consortium). The analysis of ontological structure of marriage broadly is unanimous with the text of Aquinas but the consequences formulated from it are contradictory with his moral teaching about marriage and family.

According to father Oliva the method of reinterpretation of Thomas' teaching consists in separating one sentence from wider context and 'commissioning' its

ponowoczesnego a tomistyczna teoria osoby, „Rocznik Tomistyczny”, 4(2015),

s. 191-214. 
justifying conclusions. These conclusions are absolutely contradictory with Thomas Aquinas' views which are voiced expressis verbis. Father Oliva uses this method also in respect of homosexsuality. The sentence quoted above about marriage's friendship as the biggest friendship between people is in Thomas' text one of the arguments for inseparably (indivisibilitas) of marriage and it is taken from chapter on the topic. Father Oliva takes a sentence from the text of the inseparably of marriage and in his book this inseparably is weakened in some way.

Father Oliva used a statement of Thomas Aquinas' - if a nature of some man is corrupted (natura corrupta), for this man it will be connaturale this what is contra nature (contra naturam). Thomas gives as examples cannibalism, bestiality and homosexuality. On the basis of that father Oliva writes that homosexuality being incompatible with the generally understood nature is natural for homosexual people because of their individual nature. Dominican scholar as if he had forgotten that the 'individual nature is the result of corruption (corruptio). The way out of corruption is either repair or destruction the nature. Meanwhile father Oliva proposes the third way: the acceptance of corruption. In Thomas' works we will not find basis for that acceptance.

The book of Adriano Oliva, rather proclaimed in its views, are complete misunderstanding in the sense that it completely inaccurately selected basis for the proclaimed views. St. Thomas' views are not good to justify to let to the Church's sacraments divorces remariés and institutional acceptance of homosexual couples.

Słowa kluczowe: Adriano Oliva, Tomasz z Akwinu, małżeństwo, rozwód, homoseksualizm

Key words: Adriano Oliva, Thomas Aquinas, marriage, divorce, homosexuality

Nota o autorze: Artur Andrzejuk - prof. dr hab. Kierownik Katedry Historii Filozofii Starożytnej i Średniowiecznej UKSW. Specjalizuje się w dziejach filozofii średniowiecznej, szczególnie nurtu arystotelesowskiego, w tym filozofią i teologią Tomasza z Akwinu.

\section{Bibliorgafia}

Adam A., Milost'v teológii Wincenta Granata v kontexte filozofie Tomáša Akvinského, „Rocznik Tomistyczny”, 1(2012), s. 49-63.

Andrzejuk A., Norma personalistyczna jako sposób ochrony osób w książce „Miłość i odpowiedzialność" Karola Wojtyly, w: J. Czartoszewski (red.), Ochrona życia i zdrowia człowieka w nauczaniu Jana Pawła II, Warszawa 2006, s. 185 - 191. 
Aquinas \& Homosexuality. Five Dominicans Respond to Adriano Oliva, www. firstthings.com/web-exclusives/2015/12/aquinas-homosexuality (20 VI 2016). Aristotelis, Politica libri I-II, 11, trans. Guillelmus de Morbeka, ed. Michaud-Quantisn 1961.

Arystoteles, Dzieła wszystkie, t. 6, Warszawa 2001.

Belina-Prażmowska P., Dlaczego czynimy zło? Trójpodział przyczyn zła moralnego wedtug św. Tomasza z Akwinu, „Rocznik Tomistyczny”, 3(2014), s. 113-127.

Kozerski S., Stosunek cnót do uczuć w filozofii św. Tomasza z Akwinu, na przykładzie cnoty męstwa, ,Rocznik Tomistyczny”, 3(2014), s. 99-112.

Krasnodębski M., Teoria osobowych relacji istnieniowych jako fundament rodziny w filozofii Mieczysława Gogacza, „Rocznik Tomistyczny”, 3(2014), s. 45-59.

Maritain J., Pisma filozoficzne, (tłum. J. Fenrychowa), Kraków 1988, s. 270.

Oliva A., Amours. LÉglise, les divorcés remariés, les couples homosexuels, Paris 2015.

Terruwe A., Baars C., Integracja psychiczna. O nerwicach $i$ ich leczeniu, (tłum. W. Unolt), Poznań 1987.

Tomasz Akwinu, Wykład Listu do Rzymian, (tłum. J. Salij), Poznań 1987.

Wolska U., Wizja człowieka ponowoczesnego a tomistyczna teoria osoby, „Rocznik Tomistyczny", 4(2015), s. 191-214.

www.corpusthomisticum.org (20 VI 2016). 